\title{
Brazil Woke Up Stronger? Power, Protest AND POLITICS IN 2013
}

\author{
¿Brasil despertó más fuerte? Poder, protesta y política en 2013
}

\author{
CASSANDRA SWEET \\ Pontificia Universidad Católica de Chile
}

\begin{abstract}
The year 2013 set in motion a wave of political protest the scale of which had not been witnessed in Brazil since the early 1990s. While the protests were sparked by the quotidian -an increase in Sao Paulo's metro and bus fares by $7 \%$ - they spoke to profound underlying political and economic inequalities. At their peak, the protests involved one million people and spanned a hundred cities. The demonstrators challenged both local parties and the national level PT (Partido dos Trabalhadores) leadership. This article analyzes Brazil's politics in 2013 and focuses on the genesis and significance of the June protests. Impending presidential elections loomed in the background, along with a decelerating domestic economy and the contradictions raised by the emergence of Brazil on the global stage, all of which contributed to a year of social upheaval and legislative action.
\end{abstract}

Key words: Brazil, Rousseff, protest, parties, elections, development.

\section{RESUMEN}

Brasil en el 2013 vivió una ola de protestas politicas a una escala que no se había visto desde la década de 1990. Mientras que las protestas fueron provocadas por lo cotidiano -un aumento en las tarifas de metro y autobús de São Paulo en 7\%-se abrió sobre profundas desigualdades políticas y económicas subyacentes. En su apogeo, las protestas convocaron un millón de personas y se desataron en un centenar de ciudades. Los manifestantes desafiaron tanto a los partidos locales como el liderazgo del PT a nivel nacional (Partido dos Trabalhadores). En este artículo se analiza la política de Brasil en 2013 y se hace foco en la génesis y el significado de las protestas de junio. Las inminentes elecciones presidenciales fueron el trasfondo, junto con una economía doméstica de desaceleración y las contradicciones que señala el surgimiento de Brasil en el escenario mundial, lo que contribuyó a un año de agitación social y acción legislativa.

Palabras clave: Brasil, Rousseff, protesta, partidos, elecciones, desarrollo. 


\section{INTRODUCTION}

The year 2013 set in motion a wave of political protest the scale of which had not been witnessed in Brazil since the early 1990s, when citizens revolted the perceived incompetence and chicanery of Fernando de Collor and took to the streets to demand his presidency's end. This June, nearly a generation later, Brazil again experienced a widespread and massive convulsion of protest. ${ }^{1}$ This $21^{\text {st }}$ century dissent focused not on the ousting of a single corrupt individual, but on citizens' broader disenchantment with the services of government and systems of political representation. At its peak, one million protesters marched across 100 cities, initially appealing for reduced transport costs. These demands rapidly escalated into a broader call for improved public services in health and education, and then finally the universal demand for quality governance: transparent and corruption-free state apparatus.

Protests dominated the political scene in Brazil in 2013, a year of social and political tumult in which parties faced unrest and grappled with how to capitalize on it. In particular, protesters shook up local political parties and the national PT leadership as they prepared for upcoming presidential elections in 2014. Part of the challenge to the PT had been an uphill battle to institutionalize the support held by former president da Silva and move beyond a "politics of personality" (Souza, 2011). This had been compounded by the broader disenchantment with the party system (Mische, 2013). As a result, the emergence of the protests drove the congressional agenda in the second half of the year and defined new emerging intra-party alliances. A slight increase of .9 US $\not$ in metro and bus fares triggered widespread political activity and unrest that tapped into deep political and economic inequalities and gave rise to far-reaching political consequences.

This article presents political analysis of the year 2013 in Brazil. While there were many important political shifts during the year, the dominance of the protests mid-year and their aftermath are the focus. In their backdrop, impending presidential elections, tepid economic growth, and contradictions raised by the emergence of Brazil on the global stage all contributed to a year of social upheaval and congressional legislative action.

The paper proceeds in the following structure: section two introduces the June protests; section three reviews economic policy; section four analyses important legislative advances and shifting party alliances in the face of upcoming presidential elections. The final section summarizes and speculates on what might come in 2014.

\section{STREETS, STADIUMS AND STRATEGY}

In the first week of June 2013, an autonomous, non-party affiliated social movement called the (Movimento Livre Passo or the Free Ride Movement) initiated a series of

1 The protests initiated in June and continued into mid-July. I will resist some of the more colorful names for the period -Brazilian spring, etc.- and will refer to them as the June protests. 
protests in the face of a 7\% price hike in São Paulo's public transportation fare, from $\mathrm{R} \$ 3$ to $\mathrm{R} \$ 3.20 .^{2}$ The increase disproportionately affected the working poor: workers earning the minimum wage already allocated an estimated one-fifth of their salary on transport (Conde \& Jazeel, 2013, p. 438). In this context, billions of investment in infrastructure for the hosting of upcoming World Cup games contrasted starkly and lavishly against the choices facing Brazilians who spent an important part of their income simply getting to and from work.

Throughout the year, Brazil's projected budget for infrastructure preparation and the hosting of both the World Cup and Olympics provoked political tension and skepticism as spending estimates ticked steadily upward. Doubts were raised regarding the management of these funds. (As of this writing, officials estimated US\$6 billion to host and US $\$ 18$ billion to build. $)^{3}$ Investment in these mega sporting events exacerbated longstanding, underlying debates about inequality in Brazilian cities (Caldeira, 2001; Friendly, 2013). Moreover, at a street level, ambitious plans to build and refurbish stadiums were compounded by significant social dislocation. Some estimates suggested that combined infrastructure and construction would result in the "relocation" or ousting of approximately 1.5 million Brazilians from their homes (Zimbalist, 2011). The debate about the long-term impact of this investment, its social utility and the democratic implications of the process on local communities created a backdrop of tension in many cities.

At the outset of the first transport rate hike protests in June, local media in Sao Paulo criticized the movement for worsening already ponderous traffic conditions. As the protests expanded, recorded cases of brutality by the Brazilian police generated popular sympathy. Grisly videos of citizens being beaten, pepper-sprayed and otherwise assaulted began to circulate on day two of the protests. These images and reports confirmed the widely held perception that police were brutes, fast to employ disproportionate force on the people they were legislated to protect. Initially, protesters against the fare hike had been principally comprised of activists and students. However overzealous police action and increasingly empathetic media coverage widened the demographics of protest participants. By day three of the protests, protesters came "to include hundreds of thousands of (mainly) middle-class protesters, overtly with little in common" (SaadFilho, 2013, p. 658).

"They initially had a clear organization and some specific goals [the leading group dealt with public transport and urban mobility], but the course of events has led to its fragmentation and the adding of new aims, some of which are even contradictory to the original ones (Jaime \& Aline, 2013)".

As the protests grew, protesters expanded their demands, calling for ambitious policy changes including improved public services, punishment for government corruption,

2 MPL describes itself as a "horizontal, autonomous, independent and non-party, but not anti-party". The group eschews affiliation with religious and financial groups as well as non-government organizations. (MPL, 2013). In comparison, London 2012 spent US\$14.6 billion and this year's Sochi games came in at US\$51 billion. A study by the Centre for Major Programme Management at the Said Business School in Oxford, England, showed cost overruns at the last 17 summer and winter games, with an average over spending of 179 percent. 
greater transparency in government and more democratic participation. New media and technology formats transformed the modes of organization through which these political platforms developed. Protests were organized through electronic means -online and via text messages- communication accessible to most people. Analysts drew comparisons to other protest movements emerging in 2013, such as Turkey, which shared a leaderless structure and fluid, multiple technological channels for spontaneous organization (MacKenzie, 2013).

Yet the June protests should not be described as merely product of youth's alienation or an expression of new social groups' ability to engage the power of Twitter. Nor should they be attributed just to a traditional anti-poverty movement, nor solely the intransience of violence afflicting poor communities. Some surveys suggested that protesters' profile was skewed toward the economically secure and that $79 \%$ of participants earned more than twice the mean wage (IBOPE, 2013). Other evidence pointed to extensive representation of various human rights groups, NGOs, favela resident community associations and student movements. The more diverse the protesting group, the wider the range of demands and debates. While scholars are now debating the genesis and implications of these extraordinary protests, dissenters across the country seemed to share disaffection with the state, rejecting its institutionalized partisan politics. Slogans reflected a common populist sentiment that "The people, united, do not need parties". "Right? Left? I want to go forward!" "We don't have a party. We are Brazil!" (Mische, 2013).

"These enormous demands upon the state [which arose in the protests] come in the wake of the decomposition of the traditional working-class and the demoralization and disorganization of the left parties and trade unions, after the transition to democracy, the transition to neoliberalism, and the elections of Lula and Dilma. Their outcome is that, while the middle class is confused, angry and disorganized, the workers are unhappy, mostly for different reasons, marginalized, and also disorganized. This is a recipe for political volatility, and it poses difficult problems for the left". (Saad-Filho, 2013).

Were the June protests rooted in the unresolved legacy of the PT's economic structure? Were they brought on by a broader political malaise shared by Brazil's rising middle and lower classes? What are the economic and political party implications of the June protests?

One clear source of volatility during and in the wake of the protests was the notoriously violent Brazilian police (Ahnen, 2007; Arias, 2004; Caldeira, 2002). An example is a conflict that arose on June $20^{\text {th }}$, when protesters faced "shock troop" police in Caveirões, Cavalaria, Rio de Janeiro, who lobbed tear gas, electrical shock instruments and rubber bullets into the crowd, discharging two thousand mini bombs, some of which hit and damaged the community's local Municipal Hospital Souza Aguiar. Reports of excessive force were widespread, and the Brazilian Association of Investigative Journalists reported that these types of conflicts proved dangerous for journalists as well as citizens; 117 journalists were injured in the second half of 2013 (Agence France-Presse, 2014).

Another galvanizing situation was that of Rocinha resident Amarildo de Souza, who in August 2013 was taken in for questioning by the Brazilian Military Police and allegedly 
released, but he has never reappeared. ${ }^{4}$ By the end of 2013, the Amarildo case had inspired a series of protests and a case against the military police UPP or favela pacification units.

These cases brought into sharp focus the contradictory role and conduct of various police forces. In contrast to academic literature and policy commentators who describe areas of poverty in Brazil as communities or physical spaces which are ungovernable, a new body of research finds evidence that far from "negative" spaces where government is invisible, local policing units play a seminal role in perpetrating corruption and fomenting violence in favelas (Arias, 2013; Waiselfisz, 2013). ${ }^{5}$ Part of the challenge of bringing about a meaningful reform of Brazilian police system is its splintered structure. The 1988 Constitution allowed for the continuation of two separate police institutions: "civil police" who, broadly, would attend to the investigative nature of crime and the "military police" who would be responsible for apprehension (Hunter, 1997). This division obfuscated accountability across both groups and in particular, for military police who inherited a legacy of accepted violent conduct during the military dictatorship and developed a niche for enforcement (Justiça Global, 2013).

In a number of respects, scholars suggest that the overall post-authoritarian civil-military relationship in Brazil has improved (Amorim Neto, 2012). Brazil has a Truth Commission that investigates human rights violations and it has produced a set of white papers under civilian review that lay the groundwork for police reform. Yet we now have a body of evidence which shows the significance of authoritarian regimes and their legacies on federal institutions and organization (Falleti, 2011). In terms of ensuring security, the enduring bifurcation between the military and civil police blurs accountability and obscures communication. The UN Committee on Torture and Human Rights recently recommended that Brazil eliminate its military police category. However, in 2013 Rio expanded its military police cadet program (Justiça Global, 2013). In the short-term, the federal government allocated 10,000 riot troops to be deployed across the twelve cities that will hold at World Cup in 2014.

The 2013 June protests were ignited by slight increases in urban transit fares. However, fueled by a disproportionately violent police response and disillusionment with easy spending on mega sports events and ungenerous local investment, they escalated and soon reflected broad underlying social, political and economic tensions. Lack of faith in political parties was fed by the fire of disaffection from local police and poor management of the protests. Demonstrations -not the ballot box- became a clarion call for change.

4 Another recent case of police violence that provoked civil outrage was the death of Joel, a 10-year-old boy shot in the head while sleeping during a Military Police exercise. A film about this incident was made but according to the blog of the Association of Residents of the Northeast of Amaralina, Military Police intervened and physically threatened the community when they attempted to screen the film in August 2013. For a full discussion of this case and a link to the full-length film, which has now been made available online, see http:/ / www.revistaforum. com.br/blog/2013/08/salvador-policiais-proibem-exibicao-de-documentario-sobre-morte-de-garoto-por-pms / As with all data in Brazil, it is important to note the tremendous intra-country variation. Brazil's homicide rate is 3 times higher in the small northern state of Alagoas, where it reaches more than 72 murders per 100, 000 inhabitants (this is a level of violence comparable to war-torn Colombia in the 1990s). 
Change in 2013 was difficult to bring about in the face of upcoming elections and an economy that was slowing down.

\section{POLICY, ECONOMICS AND DEVELOPMENT}

President Rousseff assumed office in early 2011, just as Brazil's economy shifted toward economic stagnation. The slowdown presented a number of policy challenges for her administration. Her predecessor had eased monetary policy and pumped reais into the economy following the 2008 global downturn. He ended his second term in the beginning of 2011, glowing in 2010's 7.5\% GDP growth and an 80\% approval rate. By 2013 , Rousseff faced a very different scenario, including low levels of overall investment, a trade balance deficit, fiscal deficit, the menace of inflation and sustained low growth. Upcoming global sporting events such as the 2014 World Cup and the 2016 Olympic Games drove investments of 13.3 USD billion and 18 USD billion (respectively), and in 2013 employment fell to an historic low. Despite these factors, Brazil followed a threeyear trajectory of dull economic performance, expanding 2.7\% in 2011, 0.9\% in 2012 and $2.3 \%$ in 2013 (IBGE, 2014). Although Brazil's initial post-2009 recovery appeared slightly more robust than that of other key emerging economies, in recent years growth receded and its GDP growth rate trailed other BRICs (Brazil-Russia-India countries). Moreover, compared to the composite indicator of Latin American and Caribbean counties, Brazil's economic growth lagged (Figure 1).

Figure 1: GDP Growth in key global economies, 1990-2013

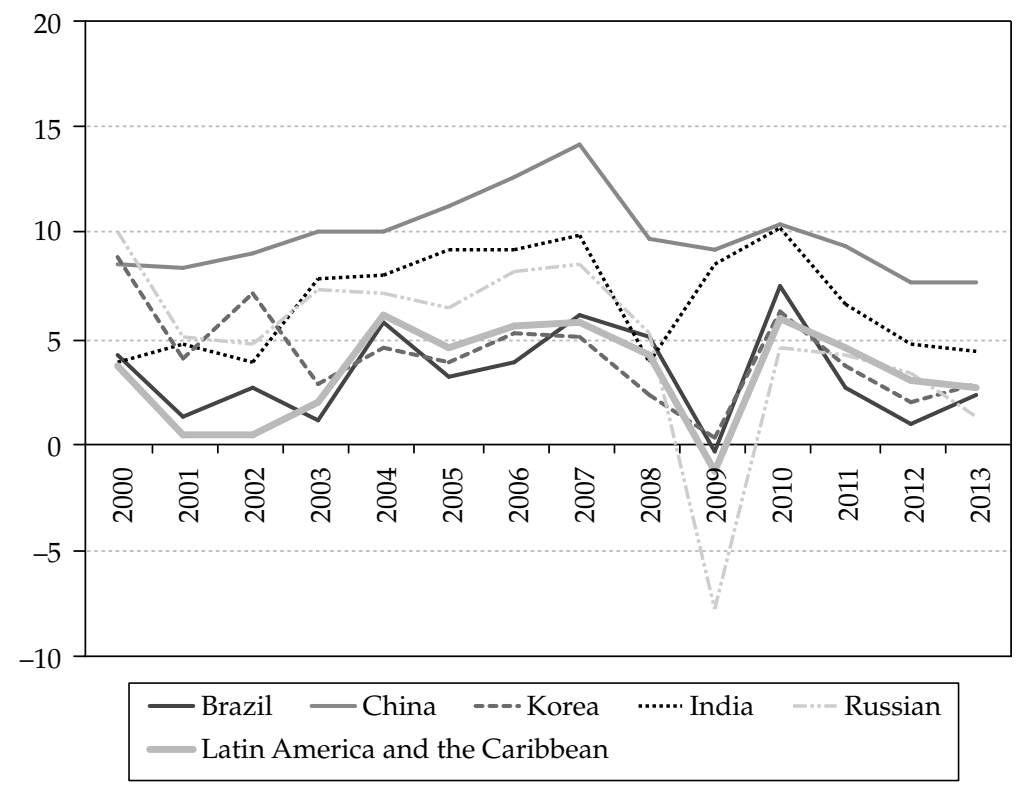

Source: Author, World Bank. 
Multiple factors accounted for this anemic growth. In the policy arena, one key factor limiting growth and public investment by the Rousseff administration was the cost of carrying a comparatively high level of public debt. In 2013, Brazil was saddled by a public debt ratio rivaling most countries in the world. Gross public debt levels reached well above $60 \%$ of GDP (see figure 2a). As a result, public debt servicing costs in 2013

Figure 2: Macroeconomic Indicators, 2013

a) Gross public debt as \% of GDP, 2013

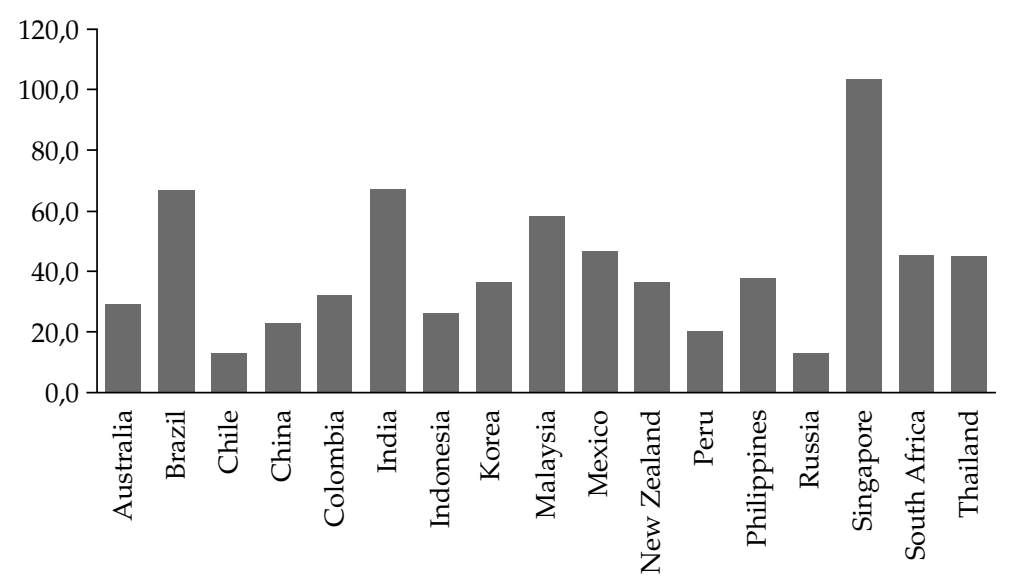

b) Fiscal balance, 2013 (GDP)

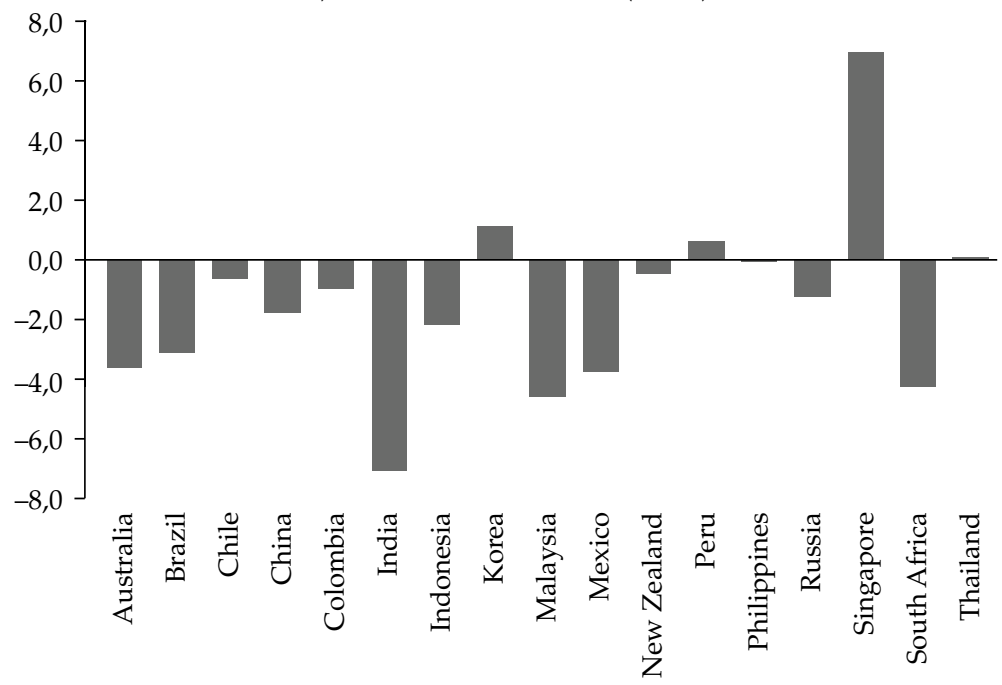

Source: Author, IMF. 
ranged around 5\% of GDP. This important disbursement toward servicing public debt added pressure on economic policy making and contributed to already low levels of investment. In 2013 combined public/private investment rate reached $18.4 \%$ compared to an average of $60 \%$ in OECD countries. The macroeconomic picture of a low growth rate, high debt ratio and meager public and private investment has spurred concern among local economists that "the world is doing well, Brazil not so much". (IBRE, 2014).

Other macroeconomic factors that contributed to a sense of economic malaise in 2013 and limited the economic policy options considered by the Rousseff administration emerged in the international arena. Over the course of the year, a global deceleration in commodity prices set off a currency devaluation of $13.3 \%$. This should have resulted in more competitive Brazilian exports, yet slowing growth in China, Brazil's second largest export markets (see Figure 3: Key Export Destinations and Products, 2011) affected its export performance. In addition, the end of quantitative easing programs in the US and UK pushed a shift toward outflows of capital. At the same time, Brazil's stock market, the BOVESPA, was one of the worst performing in the region losing $15.5 \%$ in $2013 .{ }^{6}$

Nevertheless, the exceptionally balanced nature of Brazil's export basket in both destination and composition, comprised of agricultural products $(33.8 \%)$, mining and gas $(30.4 \%)$ and manufactured products $(32.8 \%)$, provided a buffer from the economic crisis which has afflicted Europe and the United States.

Perhaps the greatest challenge that faced the Rousseff administration in the economic arena was inflation. In 2013 inflation surged and as a result, Brazil's Central Bank raised interest rates six times. By the end of the year, inter-bank interest rates had increased to $10 \%$. This was an important setback for the Rouseff administration, for which diminishing

Figure 3: Key Export Destinations and Products, 2011

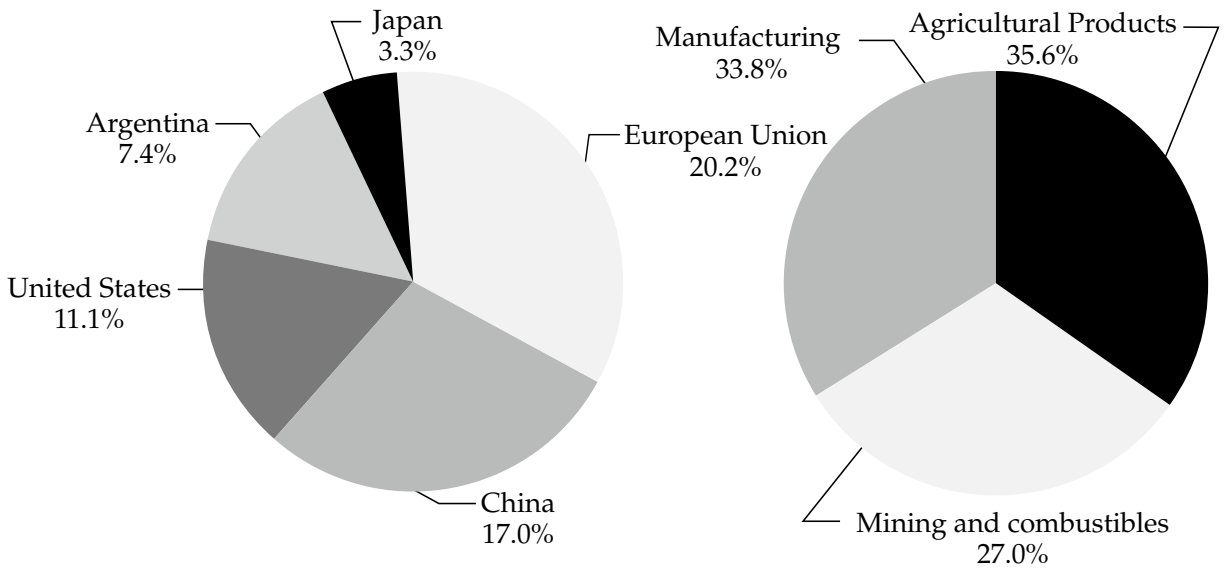

Source: Author, WTO.

6 By contrast, 2013 was kinder to US markets. The Dow surged $26 \%$, the S\&P 500 increased more than $29 \%$ and the Nasdaq ended the year up $40 \%$. 
interest rates was a key goal. This monetary tool in principle counters increases in inflation (by reducing the circulation of reais), but was also likely a factor accounting for the weakness of growth, as credit for investors, individuals and entrepreneurs became more expensive and more scarce.

The great puzzle in the Brazilian political economy in 2013 was the disjuncture between the slow growth it experienced and the resilience of its real street economy, most notably its labor market. In 2013 Brazil's labor force continued its decade long process of expansion while unemployment fell to a historic low of $5.3 \%$. What industry then was continuing to employ Brazilians in the face of a low growth/low investment rate? Many experts point to demographics are one of the key factors attributed to continued low unemployment rates. According to Brazilian Institute for Geography and Statistics, the percentage of people between the ages of 15 and 24 not in the labor force increased from $43 \%$ in 2004 to $47 \%$ in 2013. In addition, the percentage of Brazilians with nine or more years of education compared to those with nine years or less leapt from $47.8 \%$ in 2001 to $80.8 \%$ in 2009. Finally, low unemployment rates are believed to be the result of consumption generated by longterm cash-transfer programs such as the Bolsa Familia (Family Allowance), spending on sports infrastructure, decreasing inequality and high commodity prices.

Even as Brazil experienced progress in the continuing reduction of unemployment, other areas were slow to improve. In particular, measurements of the efficiency of Brazil's bureaucratic apparatus in 2013 reflected channels through which micro-level inefficiencies contributed to both the frustration of citizens and a suppression of economic growth. Four indicators developed by the World Bank -strength of legal rights, ease of doing business, time required to open a business, and time required to prepare taxes Figure 5)- offer a view of the barriers faced by Brazilian entrepreneurs.

Figure 4: Labor Market Indicators

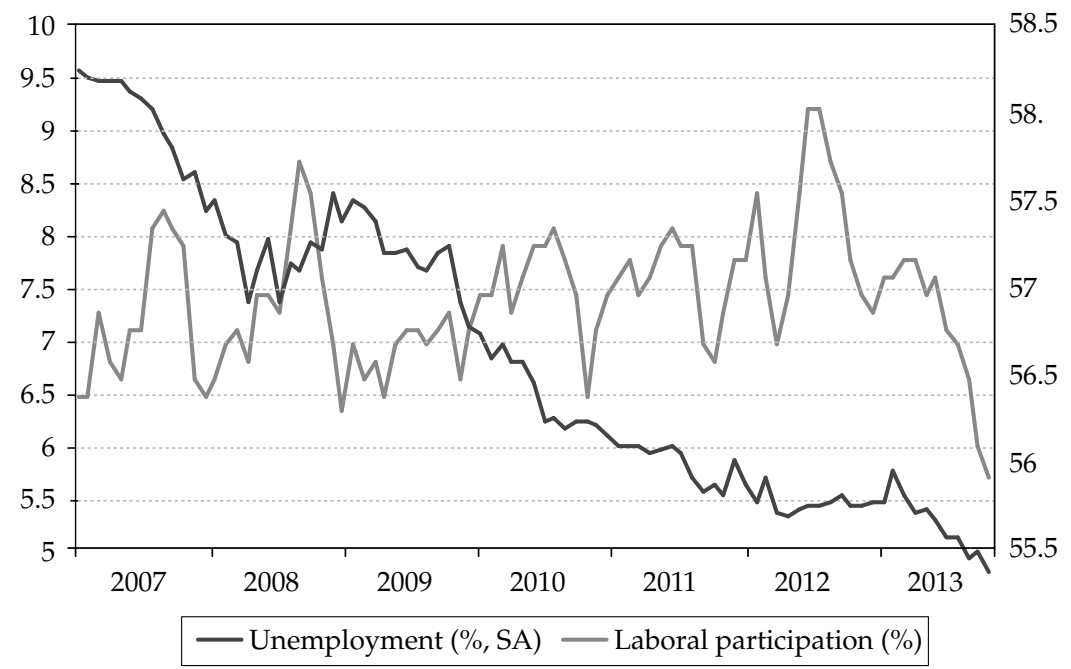

Source: Author and IMF. 


\section{Figure 5: Efficiency of Brazilian State}

a) Strength of Legal Rights (10 being most favorable)

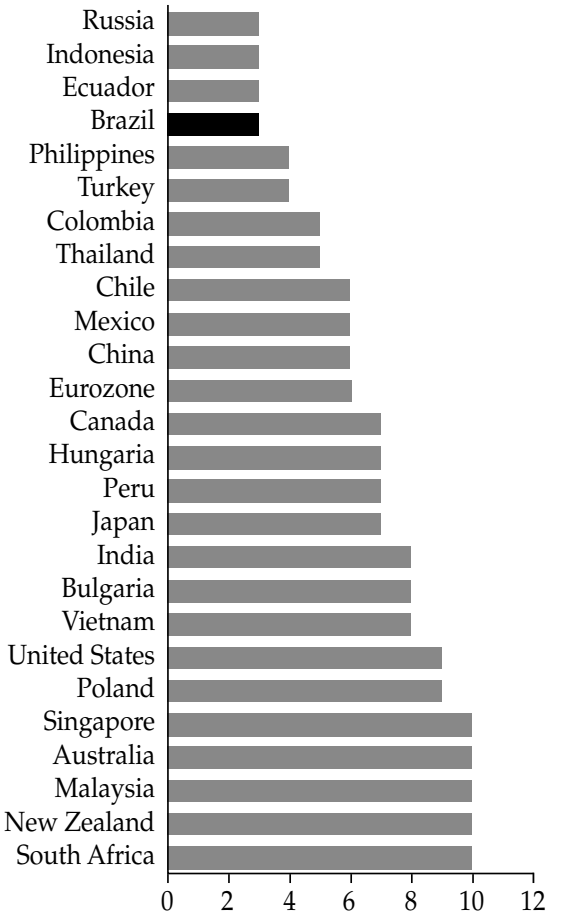

c) Time required to open a business

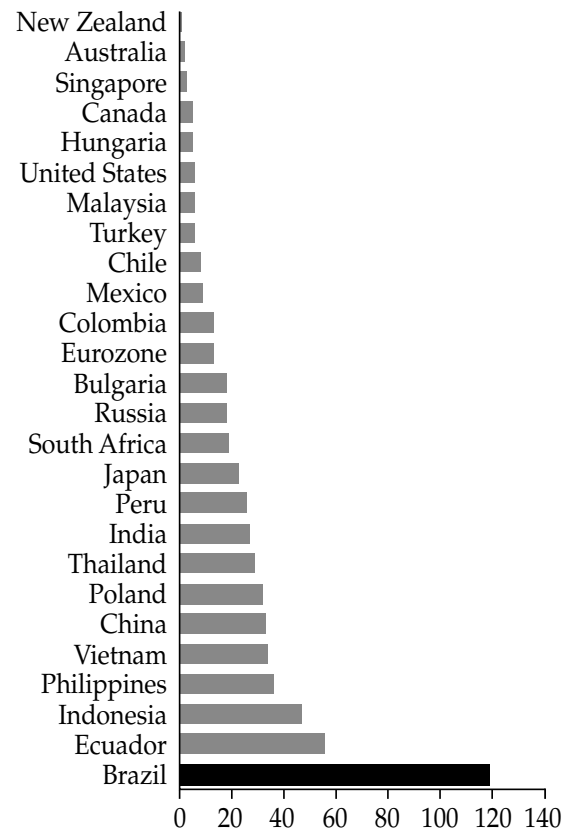

b) Ease of doing business (1 being most favorable) Singapore

New Zealand

United States

Australia

Malaysia

Canada

Thailand

Japan

Chile

South African

Eurozone

Peru

Colombia

Mexico

Hungaria

Poland

Bulgaria

Turquía

China

Vietnam

Russia

Indonesia

Brazil

India

Philippines

Ecuador

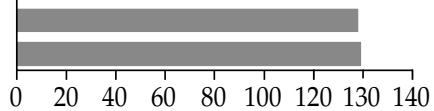

d) Time needed to prepare and pay taxes

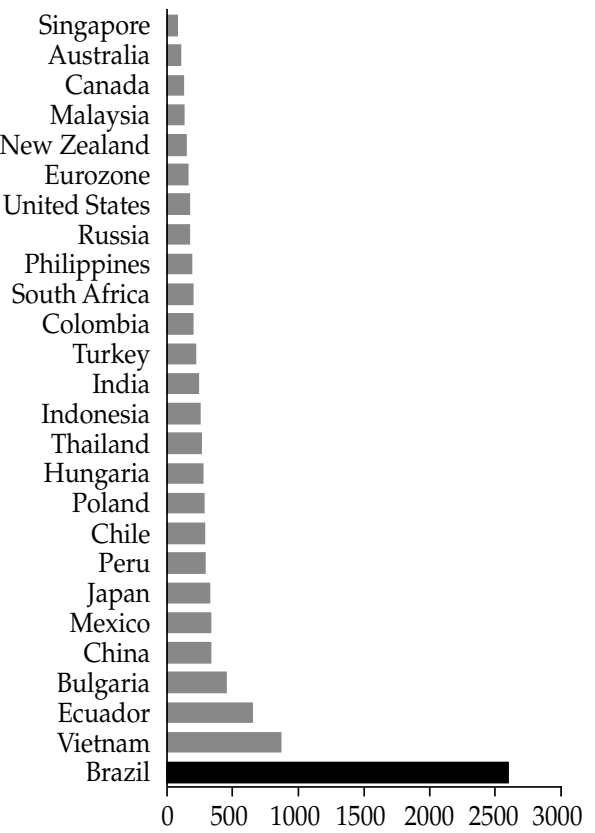

Source: World Bank, 2013. 
The combined effect of these variables is a sociopolitical environment in which the word "jeito" flourishes. "Jeitinho", in its diminutive version, describes the way in which one manipulates a situation so it goes your way. No English equivalent comprehensively covers its meaning. According to the data compiled by the World Bank, in 2013, Brazilians spent more time than any other country in the world, and twice as much time as the next country, preparing their taxes. Controlling personal tax returns may be the most potent impact a business owner can have on his financial outcomes when traditional markers of business success are stacked against a small businessperson. The World Bank has documented the lack technology and difficulty in doing business so that crucial tasks such as the opening of a new business or paying for an annual tax are transformed into onerous, lengthy burdens. A healthy economy requires business processes that are simple, standard and predictable processes, in this way hopefully insulating them from corruption. In the case of Brazil, this intricacy leaves citizens exposed to multiple instances with the potential for interference or abuse. Moreover, a half-year's worth of work is required to navigate opening a business, significant financial and chronological deterrents. ${ }^{7}$

It is no secret that the modernization of the Brazilian state has been slow and uneven. In the start of Peter Evan's classic work on industrialization, the uselessness of state officials is ridiculed in a popular parable (1995). A lion has broken loose from Brasilia's zoo and is camped out in a federal office building (the Foreign Office known as Itamarati). His absence goes unnoticed as successive bureaucrats disappear. Until, so the story goes, the person whose task it is to deliver the coffee vanishes. Brazilian bureaucrats, in this tale of state futility, would be unnoticed were they to disappear.

By 2013 however, a gentler view of the Brazilian state had emerged as evidence mounted about the effectiveness of a series of poverty reduction programs implemented over the past decade. In 2003 president da Silva enacted the Fome Zero or Zero Hunger program, an umbrella of initiatives which ranged from building wells for desert communities to providing direct cash transfers through the Bolsa Familia program. A decade later, with 36 million Brazilians having escaped extreme poverty and 50 million families having at one point been beneficiaries, the program is widely regarded as a global pioneer. ${ }^{8}$ Recipients received up to 140 reais and must comply with requirements such as keeping children in school and maintaining their vaccination routine (for program details see (Lindert, Linder, Hobbs, \& Brière, 2007). A large corpus of scholarship has mapped the positive impact of the program on health (Rivera Castineira, Currais Nunes, \& Rungo, 2009), education and poverty reduction. One recent study examined the relationship between the expansion of cash transfer programs and a declining murder rate, finding that increased participation in cash transfer programs has a positive result on reduction of homicides (Lance, 2014). Parallel to the expansion of cash transfer programs is the inculcation of health care as a human right and the guaranteeing its provision in the Brazilian medical system. Brazil

7 By contrast, according to the World Bank's 2013 report, in Ecuador it takes one-third the time it does in Brazil to complete required paperwork that makes a business official and puts it on the tax rolls.

8 The political impact of the Bolsa Família program has been widely contested. For a summary of the literature and an empirical argument that it has not served as a clientielistic tool of the PT party, see Bohn (2011, 2013). For a less sanguine view see Zucco (Zucco, 2008, 2011). 
surpasses the Unites States in the effectiveness of its HIV / AIDS program (Gómez, 2011; Kerrigan, 2010; Mahmood \& Muntaner, 2013; Parker, 2011; Sweet, 2013). This has been accompanied by the development of broad-based participatory mechanisms, such as health councils and municipal planning boards (Avritzer, 2012).

The success of the Bolsa Familia program and the decrease in inequality experienced in Brazil over the last decade (Lustig, López-Calvez, \& Ortiz-Juarez, 2013; Lustig, Pessino, $\&$ Scott, 2013) has fed the expansion of new social services. For example, one initiative developed under the Rousseff administration is the "Minha Casa Minha Vida" or My Home, My Life program. This financing program applied to recipients of the Bolsa Familia who met specific qualifications and aims to deliver of 3 million homes to Brazilian families. ${ }^{9}$ A subsequent program, "Minha Casa Melhor" or My Better Home, allowed, initiated 2013, for participants in to choose from ten different types of home furnishing and electronics products and pay a $5 \%$ interest rate with a disbursement limit up to 5,000 reais. These programs reflect the current government's interest in both addressing structural inequality and expanding consumption rates.

Figure 6: Individual Expenditure Limits on House Furnish Subsidy Program Items

Table 1. Furniture Values

With R 5.000 (USD 2.268.18), you can choose between this products:

\begin{tabular}{ll}
\hline Furniture & Maximum Selling Price \\
\hline Wardrobe & $\mathrm{R} \$ 380,00$ (USD 172.3) \\
Double Bed & $\mathrm{R} \$ 370,00$ (USD 167) \\
Single Bed & $\mathrm{R} \$ 320,00$ (USD 144.4) \\
Table with Chairs & $\mathrm{R} \$ 300,00$ (USD 135.4) \\
Couch & $\mathrm{R} \$ 375,00$ (USD 169.8) \\
\hline Appliances & Maximum Selling Price \\
\hline Refrigerator & $\mathrm{R} \$ 1090,00$ (USD 493.7) \\
Stove & $\mathrm{R} \$ 599,00$ (USD 271.3) \\
Washing Machine & $\mathrm{R} \$ 850,00$ (USD 385) \\
TV & $\mathrm{R} \$ 1400,00$ (USD 634.5) \\
Notebook with internet access or Computer with keyboard, mouse, & $\mathrm{R} \$ 1150,00$ (USD 521.2) \\
monitor with internet access & \\
\hline
\end{tabular}

* Currency rate dated May 14.

Source: Minha Casa Melhor, http://www.minhacasamelhor.org/

9 This is a gross generalization of the Minha Casa Minha Vida program, which is comprised of multiple modalities, including credit, subsidizing of housing building materials and a wide spectrum of incentives and tools for lower-income Brazilians depending on if they are urban or rural and their income/household rate. See the program's official cite (http://www.caixa.gov.br/habitacao/mcmv/) for details. 
Both these programs have been administered by the Caixa Econômica Federal, a state retail bank. Public banks have had an increasingly active role in executing the Rousseff administration's policy aims. In 2013 for example, the Brazilian development bank (BNDES) increased its credit line by $27 \%$. In its annual report on Brazil, the IMF came close to calling the current administration Keynesian, noting that "[Brazilian] authorities consider that fiscal policy can continue to play an important counter cyclical role" (IMF, 2013). Nevertheless, while Rousseff has expanded some social policy programs and increased credit on development projects, overall policy directions in 2013 were ideologically varied.

Starting in 2012 the government set forth a plan of increasing national investment by augmenting infrastructure projects and reducing energy costs. One key component of its platform proposed increasing private participation in infrastructure. This included tender concessions for new roads, ports and airports as well as an expansion of the national railroad networks with a public-private model. Reinforcing the upgrade on Brazilian transport infrastructure, the administration proposed simplifying inter-state VAT tax regulations. Rousseff granted private actors new spaces and also advocated for industry by facilitating access to credit and simplifying tax rates. One report indicated that in 2013, Brazilian industry experienced a fall in energy costs by an average $18 \%$ as a result of renegotiation of supply contracts by the government with utility providers.

The current administration has followed a heterogeneous economic policy mix. The Central Bank assumed the traditional mantel of addressing inflation. The federal government moved to privatize the management of transport links, negotiated with utilities suppliers to lower prices, provided short term consumer credit to the poor, expanded credit from its national development bank, set out a strategy for providing new houses to 3 million Brazilians in 3 years, and committed to invest 100 percent of petroleum royalties on social policies. The result is an administration that in 2013 did not shy from market intervention and cannot be described as following a standard "neoliberal model" (SaadFilho, 2013). Instead, the policy making followed by the Rousseff administration is a path of incremental change with switchbacks, retractions, and intermingled policy directions, similar to crossing a river "groping for stones" (Nolan, 2004).

In the last decade, more than 40 million Brazilians have entered the middle class. Yet Brazil has not enjoyed the sustained growth of its BRIC contemporaries. Moreover, its overall macroeconomic stability and low unemployment rate did not quell the anxieties that erupted in June's protests. Calls for more transparent and inclusive economic systems are made of an antiquated state apparatus by sixteen million citizens (roughly the size of the entire population of Chile) who continue to live in "favelas". ${ }^{10}$ That $65 \%$ of these citizens are now considered part of the Brazilian middle class reflects the contradictions that remain in Brazil's economic and political model.

10 A recent survey by Data Popular and Central Única de Favelas (CUFA), the central organization of favela inhabitants, found that consumption in the favelas tripled in the past 10 years. The project drew from statistics from two major surveys: the Pesquisa Nacional por Amostra de Domicílios (Pnad) and the Pesquisa de Orçamentos Familiares (POF) and found that residents of favelas spend approximately $\mathrm{R} \$ 56$ billion a year. 


\section{IN THE WAKE OF PROTESTS: THE “AGENDA BOMBA"?}

Facing over a million protesters across a hundred cities and the potential for protracted social and political upheaval, President Rousseff moved rapidly in the first week of the June to address some of the demands raised on the streets. Broadly speaking, her proposals in the wake of the protests can be described within a three-pronged containment strategy. The first line of action was a series of big legislative reforms responding to key complaints. These proposals would require political capital and congressional action on a number of issues that had long stagnated before the legislative body. The second prong to the Rousseff agenda can be understood as short-term relief. She negotiated with local political leaders to immediately finance transport cost reductions in cities affected by the social movements. Finally, she initiated a media campaign acknowledging, validating and affiliating herself with many of the protesters' demands: "we need to oxygenate our political system".

Rousseff was acutely aware of the political and economic costs of long-term social upheaval. She had served as minister of energy in President da Silva's first term and worked throughout the entrance of the PT into presidential power in 2003. In those first years it became evident that the entry of a leftist party into the executive branch would not negate social unrest. In the cities, protests regarding transport fares hikes were a common type of urban protest during the early da Silva years (Bruhn, 2008). Albeit on a much smaller scale than the protests taking Brazilian cities by storm in 2013, they nonetheless spurred an environment of debate and discord. In the countryside, the intractable conflict of the landless movement (MST) persisted. Though the MST had been allied with PT in the 2002 presidential elections, it doubled its land acquisitions or invasions in the first year of Lula's tenure. In return Lula was not light-handed. According to the Pastoral Land Commission, in the first year of the Lula presidency, 35,292 landless workers were evacuated from their land by force and 73 workers were assassinated in local conflicts. The rate of state-executed violence against MST members had effectively doubled with the entry of a left-leaning president (Comissão Pastoral da Terra, 2003, 2004). Political allies had rapidly turned into intransient sources of contention.

Traditional political alliances would not subdue the unrest and clear anti-partisan calls cast a shadow over the coming year's presidential election. As a result, the second half of 2013 was defined by President Rousseff's work to control the protests and assimilate their demands into a policy platform that would calm the current uproar and earn votes in 2014. Her legislative plan comprised five initiatives: 1) a proposal to address increasing inflation, 2) implementation of mechanisms for participatory involvement, 3) changes to the penal code (achieved in the third week of the protests) that consider corruption a more serious time facing a minimum incarceration of four years (previously was two), and 4) a set of proposals to restore the Brazilian public health and education systems. In the short term she proposed hiring of foreign doctors to fill vacancies in underserved communities (by the end of the year these totaled 4,000, in large part Cuban doctors) and in the medium term she proposed to increase the number of places for medical professionals in public universities. In education, the Rousseff put forth a proposal that 100 percent of royalties from oil extraction should be designated solely for spending on 
public education. The fifth and final line of Rousseff's legislative strategy was to address the trigger point of the protests with an "urban mobility agreement" that set aside USD $\$ 25$ billion for investment in public transportations systems as well as reduced taxation on diesel to lower the cost of providing transportation.

Within a week of the June protests, Brazil's Congress had brought to vote and passed a series of these reforms. While some analysts referred to this period as the "agenda bomba," quantitatively, the spate of activity did not surpass typical annual congressional output. ${ }^{11}$ Table 1 compares executive initiatives during the previous year, in the first year of President Luiz Inácio Lula da Silva's first term, and in Rousseff's first year in office.

Following a pattern established in previous years, the Rousseff administration's legislative agenda remained relatively timid. This temerity is particularly perplexing because Rousseff enjoyed majorities in both the Senate and the House of Deputes. As described by Von Bulow and Lassance (2012), these majorities permit, in theory, tight control of the legislative agenda. And yet, the temerity exhibited is one of the peculiarities of the "presidential coalitionism" of the Brazilian political system. As amply discussed in literatures on Brazilian congressional and executive power (Mainwaring, 1999; Zucco, 2010) the coalitional nature of the party system forces a construction of heterogeneous cabinets. For most of 2013, Rousseff's cabinet was comprised of no less than 6 different political parties: this mix and a wide distribution of position within sub-ministries and other important government bodies may be an explanation for less innovative executive policy agendas (Lemos, 2010).

Though in quantity, the level of legislative activity did not comprise an "agenda bomba," a number of substantively and symbolically important laws were enacted. One of the most emblematic pieces of legislation was the passage of the "passe livre estudantil," a policy granting free access to public transportation to all students (PL 2.729/11). Another piece of legislation enacted in the wake of the protests was the passage of PLC 41/13, which guarantees the allocation of royalties from petroleum sales for education and health (and PL 323/07 which establishes their division 75/25, respectively). Preliminary estimates regarding the increased spending in this area suggest an increased $\mathrm{R} \$ 112$

Table 1: $\quad$ Executive Power in 2013 (number of initiatives)

\begin{tabular}{lrrr}
\hline \multicolumn{1}{c}{ Initiative } & 2003 & 2011 & 2013 \\
\hline Executive Legislation & 32 & 27 & 30 \\
Complementary Legislation & 3 & 1 & 2 \\
Proposal for Constitutional Amendment & 2 & 2 & 0 \\
Medida Provisoria & 58 & 36 & 35 \\
\hline
\end{tabular}

Source: Adapted from (Von Bülow \& Lassance, 2012) and www.relacoesinstitucionais.gov.br. [as accessed: 01-03-2014].

11 During the legislative period of 2013, 145 propositions passed, 138 of character (lei ordinarias), two (lei complementar) and 5 as (emendas à constituição). 
billion in spending over the next ten years. The precise funding scheme will be worked out in 2014 , but roughly $50 \%$ of the new financing is expected to go directly into public education, while the other half will go into a social fund.

As her legislative agenda developed, President Rousseff's immediate strategy of negotiating with local municipal leaders to provide funding of public transport systems split federal and local opposition leaders. In particular, $\mathrm{PT}^{\prime}$ 's traditional contender, the Partido da Social Democratica Brasileira PSDB, could not maintain a united front. While Aécio Neves, the party's pre-presidential candidate lambasted the PT program in Congress, PSDB colleague and São Paulo's governor Geraldo Alckimin lauded the president's allocation $\$ 25$ billion toward urban transport improvements.

While these strategies spurred some party division, motivated some intra-party division, the post-protest moment also provided an impulse for the formation of new party alliances. On the left, to the surprise of many, in October 2013, Marina Silva, a former environmental minister for Lula and the third most voted candidate in the 2010 presidential elections, failed to submit sufficient of signatures to register her party for the 2014 presidential elections. As a result, her party was unable to put forth a presidential candidate of its own. However it could ally itself with a party that had already established those rights. Silva joined with Pernambuco governor and socialist party president Eduardo Campos (PSB). Although she holds more name recognition than Campus, Silva will be listed as vice-president on the ticket. Campus has worked to consolidate his position and enjoys his position as an effective governor who pushed Pernambuco to have one of the highest growth rates. By the end of 2013, the Campos-Silva alliance and the PT's traditional opposition party, the PSDB (Partido da Social Democracia Brasileira) candidate Aécio Neves secured his position as president of his party. Neves follows the tradition of a political dynasty, having started out his career working for his grandfather 1985's president elect Tancredo Neves. As governor of Minas Gerais he is renown for reform of the state institution called "Management Shock". According to Datafolha, one of Brazil's leading polling agencies, by the end of 2013, Rousseff held a strong lead over rivals with $47 \%$ of the intended vote, against PSDB Aécio Neves (17\%) and Eduardo Campos (12\%). Yet the ephemeral nature of polls were quickly apparent at the beginning of 2014, when Rousseff's approval ratings reached their historical low. In the face of this weakening support, President Rousseff appears to be shoring up her ministerial team. During 2013, Rousseff changed only 3 cabinet members, ${ }^{12}$ all in March, preceding the protests. But in the beginning of 2014, 9 of 25 ministers were replaced, including the crucial position of chief of staff.

Coming out of 2013, how has Brazil's political system been affected by citizen discontent, a slowing economy and the pressure of preparation for multiple global mega sporting events? Though the party system in Brazil has long been viewed as an instable, famously "inchoate democracy" (Zucco, 2010), over the past decade however, it has stabilized

12 Foreign Minister Antonio Patriota resigned from his position in August 2013 following a diplomatic dispute with Bolivia. He was quickly posted as Brazil's representative to the UN. 
and is increasingly durable (Zucco \& Power, 2011). Nevertheless, ideological differences among parties, according to one recent study, are increasingly diffuse (Kevin \& David, 2010). The legislative agenda in 2013 will now be judged by its implementation in 2014 . Will concerns articulated in the protests on broader issues of quality of life be mitigated by the recently enacted legislation? Disaffected from traditional partisan politics, Brazil's so-called "C class," or newly emergent middle class is likely to take again to the streets if concerns about corruption, education and health are not adequately addressed.

\section{SUMMARY}

Two days after street protests rippled across Brazilian cities in June 2013, president Rousseff delivered a speech in which she optimistically declared, "Brazil woke up stronger today". Following this narrative, the airing of citizens' complaints was a cathartic process, widening debate expanding citizens' rights and political participation in Brazil. According to the president: "the size of yesterday's demonstrations shows the energy of our democracy, the strength of the voice of the streets and the civility of our population" (Rousseff, 2013). Regardless whether this view was a calculated move to associate the president and her party with the protesters and diffuse their calls for real political change, 2013 brought about a number of reforms that would likely not have ensued without the impulse provided by social upheaval.

A less sanguine view of the political outcomes of the June protests might hold that even with the immediate post-protest burst of activity by Brazil's Congress, the core issues of reform of the state's police and security apparatus and the task of addressing its federal fiscal deficit were not substantively altered. ${ }^{13}$ The police were not reprimanded or restructured in light of their heavy-handedness. The economy will likely continue to decelerate with more limited opportunities for fiscal and monetary stimulus. It is possible that in the next year Brazil will be faced with increasing inflation coupled with a lowering of Brazil's sovereign debt risk rating. This will hurt access to capital and investment and continue to suppress growth rates. These drags on the economy will occur at the same time that Brazil is facing an external environment that is increasingly fraught. This will in term affect how the Rousseff administration is able to shape, maintain and further implement social policies.

The year 2013 started out on the heels of the mensalão, a major vote-buying scandal orchestrated by PT party leaders during the presidency of da Silva. In October 2012, the Supreme Court returned guilty verdicts for 25 of 37 people indicted in the scandal. During the course of 2013, as Brazilians took to the streets to demand more transparent political institutions, the Supreme Court was considering the incarceration of key leaders José

13 As of the final editing of this piece, one of the legacies of 2013 that has become evident is the enormity of the fiscal deficit bequeathed upon 2014's balance sheet. In the last days of 2013, the federal government withheld the transfer of funds to states and municipalities in a federal redistribution program called Refis. In addition the passage of $\mathrm{R} \$ 1,95$ billion to regional tax compensation for export promotion (a 1996 law called the Lei Kandir) also remained in federal coffers for 2014 (Fernandes, 2012). 
Dirceu, José Genoino and Delúbio Soares. In the closing months of 2013, the Court reached its decision: corrupted officials would serve prison time, a message of unprecedented vigor in a historical context of moral laxity in Brazilian politics. ${ }^{14}$ Broad consensus that institutional design in Brazil should be reconfigured (see 2013 legislation on corruption) will likely assume renewed emphasis in 2014, as debate on one proposed amendment to the Constitution regarding the Justice Department's jurisdiction (Ministério Público) remained in limbo at year's end. ${ }^{15}$ With new standards for punishment of corrupted officials enacted, more important still will the final procedural definition for investigation of future cases.

Finally, 2013's preparation for global mega events was taken by storm as the vast investments in new infrastructure for these sporting events cast a pall over many who perceived the spending as wasteful in light of Brazil's basic shortcomings in infrastructure and social services (Conde \& Jazeel, 2013). In her speech to the nation, in the midst of the June protests, Rousseff clarified that the funds used to build the World Cup did not come from federal coffers, but from the firms and countries that would use the new facilities. Research on spending by host nations on global sporting events and their long-term impact suggests that cities spend on average 3 times more than originally budgeted (Teigland, 1999). While all budgeted expenses are to be paid for by private actors, Brazil has committed to addressing over-budget expenses. This will present a new set of challenges in 2014 in the face of federal deficits and a softening economy.

The political scene in Brazil in 2013 was dominated by the June protests, imminent presidential elections, the relative stagnation of the economy and upcoming major sporting events. Will 2014 be marked by chaos and social upheaval? Or will the year's exercises in electoral politics and global sportsmanship serve as a platform for exalting national pride and deepening democratic institutions? Presidential elections will be held in October 2014. The World Cup will kick off just five months earlier. If, as the president has claimed, 2013's protests have reinforced and invigorated Brazil's democratic institutions, this newfound strength will be thoroughly tested in 2014.

\section{REFERENCES}

Agence France-Presse. 2014. Journalist declared brain dead after being hit by flare during Brazilian protest. The Raw Story, http://www.rawstory.com/rs/2014/02/10/ journalist-declared-brain-dead-after-being-hit-by-flare-during-brazilian-protest/.

Ahnen, R.E. 2007. "The Politics of Police Violence in Democratic Brazil". Latin American Politics and Society 49 (1): 141-164. doi: 10.1111/j.1548-2456.2007.tb00377.x

Amorim Neto, O. 2012. Democracy, Civil-Military Relations and Defense Policy in Brazil. APSA 2012 Annual Meeting Paper, Available at SSRN: http:/ /ssrn.com/abstract=2110718.

14 If this statement reads too broadly formed, by comparison one should consider the "Sanguessuga" or "Bloodsucking" scandal of 2006. In this instance, 91 members of Congress (almost a fifth of members in the House of Representatives) were investigated for participating in a scheme that diverted funds from the public purchase of ambulances. Following a Congressional inquiry or Comissão Parlamentar de Inquérito (CPI), no indictments were made and no jail time was served though it was estimated R $\$ 110$ million had been poached from Ministry of Health budgets.

15 Proposta de Emenda à Constituição, or PEC37. 
Arias, E.D. 2004. "Faith in Our Neighbors: Networks and Social Order in Three Brazilian Favelas". Latin American Politics and Society 46 (1): 1-38. doi: 10.1111/j.1548-2456.2004.tb00264.x

Arias, E.D. 2013. "The Impacts of Differential Armed Dominance of Politics in Rio de Janeiro, Brazil". Studies in Comparative International Development 48(3): 263-284. doi: 10.1007/s12116-013-9137-8.

Avritzer, L. 2012. “The Different Designs of Public Participation in Brazil: Deliberation, Power Sharing and Public Ratification". Critical Policy Studies 6 (2): 113-127. doi: 10.1080/19460171.2012.689732.

Bohn, S.R. 2011. "Social Policy and Vote in Brazil: Bolsa Famiília and the Shifts in Lula's Electoral Base". Latin American Research Review 46 (1): 54-79.

Bohn, S.R. 2013. "The Electoral Behavoir of the Poor in Brazil: A Research Agenda". Latin American Research Review 48 (2): 25-31.

Bruhn, K. 2008. Urban Protest in Mexico and Brazil. Cambridge: Cambridge University Press.

Caldeira, T. 2001. City of Walls: Crime, Segregation and Citizenship in Sao Paulo. Berkeley: University of California Press.

Caldeira, T. 2002. "The Paradox of Police Violence in Democratic Brazil". Ethnography 3 (3): 235-263.

Cardoso, D. 2013. "China-Brazil: A Strategic Partnership in an Evolving World Order". East Asia 30 (1): 35-51. doi: 10.1007/s12140-012-9186-z

Comissão Pastoral da Terra. 2003. Conflictos no Campo 2002. Goiânia, Comissão Pastoral da Terra.

Comissão Pastoral da Terra. 2004. Conflitos no Campo 2003. Goiânia, Comissão Pastoral da Terra.

Conde, M., \& Jazeel, T. 2013. Kicking Off in Brazil: Manifesting Democracy. Journal of Latin American Cultural Studies 22 (4): 437-450. doi: 10.1080/13569325.2013.840278

Evans, P. 1995. Embedded Autonomy: States and Industrial Transformation. Princeton: Princeton University Press.

Falleti, T. 2011. "Varieties of Authoritarianism: The Organization of the Military State and its Effects on Federalism in Argentina and Brazil". Studies in Comparative International Development 46 (2): 137-162. doi: 10.1007/s12116-010-9077-5

Fernandes, A. 2012. Resultado fiscal de 2013 pressiona contas em 2014. O Estado de Sao Paulo, January 13(http:/ / economia.estadao.com.br/noticias/economia-brasil,resultado-fiscal-de-2013-pressionacontas-em-2014,175128,0.htm).

Friendly, A. 2013. "The Right to the City: Theory and Practice in Brazil". Planning Theory \& Practice 14 (2): 158-179. doi: 10.1080/14649357.2013.783098

Gómez, E.J. 2011. "How Brazil Outpaced the United States When It Came to AIDS: The Politics of Civic Infiltration, Reputation, and Strategic Internationalization". Journal of Health Politics, Policy and Law 36 (2): 317-352.

Hunter, W. 1997. Eroding Military Influence in Brazil. Chappell Hill: University of North Carolina Press. IBRE. 2014. O mundo vai bem, o Brasil nem tanto, diz economista. Noticias IBRE, Rio de Janeiro(19/03). Jaime, O., \& Aline, K. 2013. Renewal of Democracy in Brazil's Protests. Economic and Political Weekly 48 (29). Justiça Global. 2013. Não é só por vinte centavos, é pela desmilitarização das polícias, pelo fim da violência policial. Arquivo da Justiça Global, 15H21.

Kerrigan, D. 2010. "The Politics and History of AIDS Treatment in Brazil". Global Public Health 5 (3): 313-315. doi: 10.1080/17441690903449303

Kevin, L., \& David, S. 2010. "The Ideological "Coherence" of the Brazilian Party System, 1990-2009". Journal of Politics in Latin America 2 (3): 39-69.

Lance, J.E. 2014. "Conditional Cash Transfers and the Effect on Recent Murder Rates in Brazil and Mexico". Latin American Politics and Society 56 (1): 55-72. doi: 10.1111/j.1548-2456.2014.00221.x

Lemos, L.B. 2010. The New President and the New Congress 2011: Challenges Ahead. Presented at Brazil in the world context: challenges and perspectives, reie universität, Berlin, February.

Lindert, K., Linder, A., Hobbs, J., \& Brière, B.n.d.d.l. 2007. The Nuts and Bolts of Brazil's Bolsa Família Program: Implementing Conditional Cash Transfers in a Decentralized Context. World Bank, May.

Lustig, N., López-Calvez, \& Ortiz-Juarez. 2013. "Declining Inequality in Latin America in the 2000s: The Cases of Argentina, Brazil, and Mexico". World Development 44: 129-141.

Lustig, N., Pessino, C., \& Scott, J. 2013. "The Impact of Taxes and Social Spending on Inequality and Poverty in Argentina, Bolivia, Brazil, Mexico, Peru, and Uruguay: Introduction to the Special Issue". Public Finance Review 42 (3): 287-303.

MacKenzie, D. 2013. "Brazil's Uprising Points to the Rise of Leaderless Networks". New Scientist 218 (2923): 9. 
Mahmood, Q., \& Muntaner, C. 2013. "Politics, Class Actors, and Health Sector Reform in Brazil and Venezuela". Global Health Promotion 20 (1): 59-67.

Mainwaring, S. 1999. Rethinking Party Systems in the Third Wave of Democratization: The Case of Brazil. Stanford, California: Stanford University Press.

Mische, A. 2013. "Come to the Streets, but Without Parties": The Challenges of the New Brazilian Protests. [Blog post]. Mobilizing Ideas, September 4: 1-3.

MPL. 2013. Carta de Principios: Movimento Passe Livre. http://saopaulo.mpl.org.br/apresentacao/ carta-de-principios/.

Nolan, P. 2004. China at the Crossroads. Cambridge: Polity Press.

Parker, R. 2011. "The Politics and History of AIDS Treatment in Brazil - by Nunn, Amy". Bulletin of Latin American Research 30 (4): 526-528. doi: 10.1111/j.1470-9856.2011.00558.x

Rivera Castineira, B., Currais Nunes, L., \& Rungo, P. 2009. "Impacto de los programas de transferencia condicionada de renta sobre el estado de salud: el Programa Bolsa Familia de Brasil". Revista Española de Salud Pública 83: 85-97.

Rousseff, D. 2013. Discurso da Presidente Dilma. http://noticias.uol.com.br/cotidiano/ ultimas-noticias/2013/06/21/em-pronunciamento-dilma-diz-que-chamara-prefeitos-e-governadorespara-discutir-mobilidade-urbana.htm.

Saad-Filho, A. 2013. "Mass Protests under 'Left Neoliberalism:' Brazil, June-July 2013". Critical Sociology 39 (5): 657-669.

Souza, A. d. 2011. "The Politics of Personality in Brazil". Journal of Democracy 22 (2): 75-88.

Stephen, M. D. 2012. "Rising Regional Powers and International Institutions: The Foreign Policy Orientations of India, Brazil and South Africa". Global Society 26 (3): 289-309. doi: 10.1080/13600826.2012.682277

Sweet, C. 2013. "The Political Economy of Pharmaceuticals in Brazil". In H. Lofgren \& O. Williams (Eds.), Global Pharmaceutical Politics and Production, 29-47. London: Palgrave.

Teigland, J. 1999. "Mega-events and impacts on tourism; the predictions and realities of the Lillehammer Olympics". Impact Assessment and Project Appraisal 17 (4): 305-317. doi: 10.3152/147154699781767738

Vieira, M. A., \& Alden, C. 2011. "India, Brazil, and South Africa (IBSA): South-South Cooperation and the Paradox of Regional Leadership". Global Governance: A Review of Multilateralism and International Organizations 17 (4): 507-528. doi: 10.5555/1075-2846-17.4.507

Von Bülow, M., \& Lassance, A. 2012. "Brazil después de Lula: Más de lo Mismo?" Revista de Ciencia Politica 32 (1): 49-64.

Waiselfisz, J.J. 2013. Mapa da Violência 2013. Homocídios e Juventude no Brasil, CBELA Contro Brasileiro de Estudos Latino-Americanos. FLACSO Brasil.

Zimbalist, A. 2011. Can Brazil Build the Massive Infrastructure it Needs to Host the Olympics and the World Cup? Americas Quarterly, Summer (Americas Society and Council of the Americas).

Zucco, C. 2008. "The President's "New" Constituency: Lula and the Pragmatic Vote in Brazil's 2006 Presidential Elections". Journal of Latin American Studies 40 (01): 29-49.

Zucco, C. 2010. Stability Without Roots: Party System Institutionalization in Brazil. Getulio Vargas Foundation Working Paper.

Zucco, C. 2011. Conditional Cash Transfers and Voting Behavior: Redistribution and Clientelism in Developing Democracies. Princeton; Woodrow Wilson School, Princeton University.

Zucco, C., \& Power, T. 2011. "Elite Preferences in a Consolidating Democracy: The Brazilian Legislative Surveys, 1990-2009". SSRN eLibrary, http:// ssrn.com/abstract=2025610

Cassandra Sweet is professor of political science at Universidad Católica de Chile. Professor Sweet received her PhD from the University of Cambridge, where she also completed a Master's degree in development studies. Her research focus is on the political economy of development, with particular interest in innovation, access to medicine and development cooperation. She has published a number of studies on intellectual property, regulation of pharmaceuticals, emerging market multinationals and the politics of development in India, Brazil and Latin America. Her consulting work has included projects for the World Bank, the United Nation's Economic Commission on Latin America (CEPAL) and the French national research agency ANRS. In 2013, she was selected by the Universidad Católica to receive a "Premio Excelencia en Docencia," for recognition of outstanding teaching. E-mail: csweet@uc.cl 